\title{
Strukturerade intervjuer som underlag för utvärdering och forskning - några metodologiska aspekter
}

\author{
MIKAEL DAHLBERG \& MATS ANDERBERG
}

Strukturerade intervjuer har fätt en ökad användning inom socialt arbete. Den här artikeln beskriver hur en strukturerad intervju kan utgöra underlag för att lokalt utvärdera om klienter inom missbrukarvården fär sina hjälpbehov tillgodosedda under behandlingstiden. Ett antal metodologiska frägor lyfts fram och diskuteras.

Inom socialt arbete är det mindre vanligt att de olika typer av interventioner som klienter blir föremål för utvärderas, trots det senaste decenniets omfattande satsningar på området från centralt håll (Tengvald 2006). En sådan ansträngning var projektet för nationellt stöd till kunskapsutveckling inom socialtjänsten (KUBAS) som strävade efter att minska klyftan mellan praktik, forskning och utbildning i socialt arbete

Mikael Dahlberg, doktorand, institutionen för vårdvetenskap och socialt arbete, Växjö universitet Mats Anderberg, doktorand, institutionen för vårdvetenskap och socialt arbete, Växjö universitet i syfte att få till stånd ett arbete med klienter som i större utsträckning baseras på vetenskapliga rön eller lokala uppföljningar. I linje med det har olika myndigheter som t.ex. Forskningsrådet för arbetsliv och socialvetenskap (FAS), Statens institutionsstyrelse (SiS) samt Mobilisering mot narkotika (MOB) också bidragit med betydande anslag till studier av sociala interventioner. Ytterligare en satsning är tillskapandet av Institutet för utveckling av metoder i socialt arbete (IMS) på Socialstyrelsen som bl.a. har i uppdrag att stödja eller genomföra studier av olika insatser och åtgärder inom socialt arbete. 
Insatser inom missbrukarvården har ofta legitimerats på helt andra grunder än att de kan visa upp goda resultat. Det kan exempelvis handla om att ge utsatta människor omvårdnad eller skydd, avlasta anhöriga samt kontroll av oönskade beteenden (Bergmark \& Oscarsson 1992, Blomqvist 2000). Att utvärdera vad sociala interventioner resulterar i innehåller emellertid även en etisk dimension:

Det är överhuvudtaget mycket svårt att /.../ hitta ett enda argument som ger stöd för att inte utvärdera de insatser som samhället genomför gentemot medborgarna, $i$ synnerhet mot dem som har en svag eller utsatt position $i$ det sociala sammanhanget. Ofta är dessa insatser förknippade med en uttalad eller outtalad maktutövning, $i$ vissa fall direkt förenad med långtgående tvångsinslag. Att utöva tvaing utan att kunna legitimera detta med belägg för att det 'för något gott med sig' borde vara uteslutet i ett något så när sofistikerat samhälle. Men såär långt ifrain fallet (Börjeson 2005 s. 224).

Varför är det så svårt att få till stånd utvärderingar av det sociala arbetets olika insatser? Bergmark och Lundström (2007) menar att det är komplicerat att utvärdera effekter i syfte att nå generaliserbar kunskap i socialt arbete, då alltför få verksamheter har ett tydligt metodinnehåll. En annan bidragande faktor är att den befintliga dokumentationen främst tillgodosett administrativa eller juridiska krav och har befunnits vara alltför bristfällig för att kunna utgöra en grund för uppföljning av klienter eller för utvärdering av olika verksamheter (ibid, Billquist \& Johnsson 2007).
För att kunna utvärdera behandlingsinsatser krävs dokumentation om klienten när behandlingen påbörjas, vid avslutning eller uppföljning samt dokumentation om den specifika behandlingsinsatsen. Det är i detta sammanhang de standardiserade intervjumetoderna ges en central roll, där klienternas lämnade uppgifter ska kunna ge ett underlag för såväl lokal utvärdering som forskningsaktiviteter. Till följd av det har omfattande satsningar även på detta område gjorts från centrala myndigheter för att komma tillrätta med bristerna (Socialstyrelsen 2001, 2004). I den här artikeln undersöks och diskuteras strukturerade intervjuer som underlag för lokal utvärdering.

I de nyligen utgivna nationella riktlinjerna för missbruks- och beroendevård ägnas frågor om strukturerade intervjuer eller bedömningsinstrument särskild uppmärksamhet. Här rekommenderas ett antal olika instrument för olika syften eller användningsområden, från problemidentifiering med enklare självrapporteringsformulär till en mer omfattande dokumentation baserad på strukturerade intervjuer som syftar till att utgöra underlag för behandlingsplanering och utvärdering av behandlingsresultat (Socialstyrelsen 2007).

För uppföljning och utvärdering av behandlingsinsatser har intervjumetoderna ASI och DOK rekommenderats. ${ }^{1}$ Men även

1 ASI = Addiction Severity Index, en semistrukturerad intervju med amerikanskt ursprung som fått stor spridning över hela världen. DOK =Dokumentation av klienter, en semistrukturerad intervju som utvecklats av SiS och IKM vid Växjö Universitet. 
om dessa båda instrument används i allt större omfattning inom svensk missbruksvård, tycks det fortfarande vara begränsat med forskning eller lokala utvärderingar om vad resultatet av olika behandlingsinsatser för klienter blir. Troligen kan det bero på avsaknad av såväl tid och resurser som kunskap om hur man praktiskt kan gå tillväga för att sammanställa den insamlade informationen (Socialstyrelsen 2002).

\section{Olikafokus vid utvärdering}

Vid utvärdering av behandling avses främst process och resultat. Med det förstnämnda menas det som sker under behandlingstiden, medan det sistnämnda fokuserar på de förändringar som uppstår till följd av interventionen, dels i samband med avslutad behandling men också på längre sikt en tid efter denna. Distinktionen mellan process och resultat är i sig komplicerad, då det som sker under behandling sannolikt har stor betydelse för de förändringar som uppstår efter den (Hill \& Lambert 2004, Rossi et al. 2003).

McLellan et al. (2005) förespråkar en utvärderingsmodell som också uppmärksammar de kortsiktiga förändringarna, de som uppträder under behandlingstiden. För att kunna identifiera de sannolikt största förbättringarna hos klienter i behandling hävdas vikten av att särskilt mäta förändringar i samband med avslutad behandling. Finney (2003) drar liknande slutsatser och menar att forskningen ofta förbisett de kortsiktiga men viktiga förändringarna hos klienterna. Även Börjeson (2005) anser att det kan vara fullt tillräckligt med sådana s.k. före-efterstudier på lokal nivå för att få svar på frågan om den studerade interventionen medför förbättringar för klienter eller ej:

Studier som innebär uppföljning av en grupp av individer vid upprepade tillfällen - man jämför alltså individerna med sig själva - kan under vissa omständigheter ge väl underbyggda slutsatser rörande effekten av behandlingsinsatser som riktats mot gruppen ifråga(s. 222).

Utvärdering av behandling kan således inriktas antingen på innehållet eller på vilka förändringar som äger rum för klientens del. Klienternas egna uppgifter om förändringar och synpunkter på den behandling de varit föremål för är en viktig beståndsdel i sådana utvärderingar. En grundläggande tanke med de strukturerade intervjuerna av typen ASI och DOK är bl.a. att fånga klienternas uttryckta hjälpbehov före och efter en behandling (Stenius \& Room 2004).

Att låta klienters egna uppgifter och perspektiv vara vägledande - inte bara som grund för behandlingsplanering - utan även i ett fortsatt motivations- och behandlingsarbete, har visat sig ha stor betydelse också för behandlingsresultatet (Miller \& Wilcombe 2002, SBU 2001). I en evidensbaserad praktik ägnas också klientens egna uttryckta behov och perspektiv stor uppmärksamhet i kombination med klinisk expertkunskap och stödjande forskningsresultat (Oscarsson 2006). När det gäller intervjumetoder av den här typen visar det sig att klienter i hög grad accepterar att bli intervjuade och ställer sig positiva till att underlaget används för att kunna reflektera 
över sin situation (Engström \& Armelius 2002, Lauritzen \& Ravndal 2004).

\section{Syfte och frågeställningar}

DOK är ett dokumentationssystem som används inom stora delar av den svenska missbruksvården. Systemet utvecklades under 90-talet i samarbete mellan praktiker och forskare kopplade till både den frivilliga missbruksvården och tvångsvården. Syftet var att initiera kvalitets- och metodutveckling inom missbrukarvården på en vetenskaplig grund. Dokumentationen består av strukturerade klientintervjuer som genomförs i samband med inskrivning, utskrivning och uppföljning. Intervjuerna kartlägger klientens olika livsområden och består huvudsakligen av slutna frågor, men det förekommer även ett antal öppna frågeställningar. För klienten kan dokumentationen utgöra underlag för behandlingsplanering och uppföljning. Intervjusvaren överförs sedan till en databas som möjliggör aggregering av insamlad data som grund för verksamhetsbeskrivning, kvalitetsutveckling, utvärdering och forskning (Jenner \& Segreaus 2005).

Den strukturerade intervjumetoden DOK har i tidigare studier granskats och analyserats avseende metodologisk kvalitet (Anderberg \& Dahlberg 2007, Dahlberg \& Anderberg 2007, 2008). I det fortgående forsknings- och utvecklingsarbetet utförs specifika studier om instrumentet som underlag för sammanställningar av behandlingsresultat. I en av dessa studier, som finansieras av Mobilisering mot narkotika (MOB), ingår ett särskilt uppdrag där frågan om huruvida ett bedömningsinstrument som exempelvis DOK kan användas för att undersöka om klienter i missbruksbehandling får sina hjälpbehov tillgodosedda. Det innebär även en metodologisk granskning av såväl inskrivnings- och utskrivningsintervjuernas konstruktion som det underlag dessa genererar.

Syftet med denna artikel är således att beskriva och diskutera på vilket sätt intervjumetoden DOK kan utgöra underlag för att utvärdera om klienter vid en behandlingsenhet inom missbrukarvården får sina hjälpbehov tillgodosedda under behandlingstiden. De specifika frågeställningarna är följande:

- Vilka hjälpbehov uttrycker klienter vid inskrivning i behandling?

- I vilken utsträckning uppfattar klienterna att dessa hjälpbehov har blivit tillgodosedda under behandlingstiden?

- Vad har klienterna upplevt som särskilt betydelsefullt under behandlingen när det gäller förändring av sin livssituation?

\section{Metod}

Studien baseras på ett fall och exemplifierar i första hand huruvida dokumentationen från intervjumetoden DOK kan utgöra ett underlag för att utvärdera om klienternas hjälpbehov tillgodoses under behandlingstiden. Att undersöka och pröva hur en arbetsmodell eller ett arbetssätt fungerar i en specifik kontext kan med fördel göras med en fallstudie. Fallstudien kännetecknas av att ett fenomen studeras på ett 
fördjupat sätt i sitt naturliga sammanhang, vanligen med olika empiriska angreppssätt eller källor som kan vara av såväl kvalitativ som kvantitativ art (Yin 2003). Föreliggande studie baseras på befintlig dokumentation som samlats in genom strukturerade intervjuer med klienter i samband med påbörjad och avslutad behandling på en enhet inom den frivilliga missbruksvården. Intervjuerna, som genomförts med DOK som stöd, innehåller både bundna och öppna frågor.

Den enhet där studien genomförts är ett behandlingshem inom den frivilliga missbruksvården där strukturerade intervjuer med klienter utförts sedan flera år. Dokumentationen används som underlag för behandlingsplanering, men också för verksamhetsutveckling. Behandlingsenheten är belägen i landsbygdsmiljö, har funnits i drygt 20 år och tar årligen emot ca 80 klienter med olika typer av missbruksproblem. Behandlingspersonalen, som är drygt 20 till antalet, består av socionomer, psykoterapeuter, socialpedagoger, fritidsledare samt medicinsk personal. Behandlingen bygger, enligt befintligt informationsmaterial, på en kognitiv och systemteoretisk grund med tydligt fokus på social rehabilitering. Ur behandlingsinnehållet anges följande inslag: Individuella samtal och psykoterapi i grupp, läkemedelsnedtrappning, återfallsprevention, familje- och nätverksarbete, fobiträning och behandling av tvångssymptom, ångesthantering, social planering gällande boende, ekonomi, sysselsättning, skolgång och myndighetskontakter, terapiträdgård och skapande verksamhet samt fysisk träning och massage. Som framgår av innehållet berör interventionerna huvudområdet drogmissbruk, men i en relativt rik omfattning strävar behandlingen även till förbättringar inom livsområden som psykisk hälsa, relationer, social situation, fysisk hälsa och fritid.

Av de 66 klienter som under hösten 2006 t.o.m. våren 2007 avslutade sin behandling på enheten, valde 51 personer att medverka i forskningsprojektet. De klienter som deltog informerades om syftet med studien, att de när som helst kunde avbryta sitt deltagande utan sanktioner och utan att ange skäl samt att studien var frikopplad från själva behandlingen. Ytterligare tio personer har fallit bort eftersom de enbart har dokumenterats med den korta versionen av utskrivningsintervjun, vilket inte varit tillräckligt för att besvara studiens syfte. Anledningen till den kortare intervjun är att de tio personerna har avslutat eller avbrutit behandlingen i förtid. Tabell 1 ger en beskrivning av de 41 personer som kom att ingå i undersökningsgruppen.

Noterbart beträffande undersökningsgruppen är att andelen kvinnor är något större än den könsfördelning som vanligtvis återfinns inom svensk missbruksvård. Medianåldern är 39 år och de flesta klienterna är ensamstående. En övervägande del av dem har tidigare vårdats för missbruksproblem och en mycket stor del har också uppgett att de har psykiska problem. Hälften av klienterna är i behandling primärt för alkoholmissbruk, en tredjedel för narkotikamissbruk och resterande för sitt läkemedelsmissbruk. De 41 klienter som följts upp har en genomsnittlig behandlingstid på åtta månader. Bortfallet innebär att undersökningsgruppen, där de flesta

Mikael Dahlberg \& Mats Anderberg: Strukturerade intervjuer som underlag... 
har fullföljt sin behandling, sannolikt är något selekterad $\mathrm{i}$ relation till en grupp med klienter där fler avbryter sin behandling i förtid.

\section{Instrument och genomförande}

DOK är en strukturerad intervjumetod som består av fyra olika formulär: inskrivning när behandlingen påbörjas, avstäm-

\section{Tabell I.}

En beskrivning av undersökningsgruppen, $n=41$. Procentuell fördelning (\%).

\begin{tabular}{lc}
\hline Kön: & \\
Män & 63 \\
Kvinnor & 37 \\
Boendeform senaste 6 mån: & \\
Eget boende & 80 \\
Institution & 10 \\
Tillfälligt boende & 10 \\
Levnadsform senaste 6 mån: & \\
Ensamlevande & 83 \\
Samlevande & 17 \\
Barn under I 8 år: & 49 \\
Försörjning senaste 6 mån: & \\
Lön, sjukpenning,A-kassa & 36 \\
Försörjningsstöd & 34 \\
Sjukbidrag, pension & 22 \\
Annan & 7 \\
Primär drog: & \\
Alkohol & \\
Narkotika & \\
Läkemedel & 49 \\
Tidigare missbruksvård: & 32 \\
Fysiska problem: & 20 \\
Psykiska problem: & 80 \\
Dömd för brott: & 49 \\
\hline & 90 \\
\hline & 54 \\
\hline
\end{tabular}

ning under behandlingstiden, utskrivning när behandlingen avslutas och uppföljning som sker en tid efter avslutad behandling, oftast efter sex eller tolv månader. Frågeformulärens innehåll bygger på en struktur med en kartläggning av olika livsområden, som även återfinns i ASI. Den långa versionen av intervjun tar cirka en timme och den korta versionen, som är konstruerad för att även kunna dokumentera klienter med stöd av aktmaterial, tar cirka 15 minuter att genomföra. I denna studie har dokumentationen från in- och utskrivningsintervjun använts som underlag.

Intervjuerna utfördes av personal med utbildning i och vana av att genomföra strukturerade intervjuer i samband med inskrivning och utskrivning. Uppgifterna registrerades i den databas som är knuten till DOK-systemet. Datainsamlingen skedde under åren 2006 och 2007, intervjumaterialet sammanställdes, bearbetades och analyserades sedan i SPSS (Statistical Package of Social Sciences).

Utifrån studiens syfte gjordes ett urval av variabler i inskrivnings- och utskrivningsintervjuerna som avser belysa klienternas förändrade hjälpbehov. Följande variabler jämfördes och analyserades för att åskådliggöra förändring: klientens skattning av oro, förändring samt stöd och hjälp. Nämnda skattningar sker för intervjumetodens samtliga elva livsområden. För att ytterligare lyfta fram hur klienternas synpunkter kommer till uttryck i den strukturerade intervjun valdes även en öppen fråga ur utskrivningen, som avser att illustrera vad klienterna har upplevt som särskilt betydelsefullt i behandlingen. 


\section{Analys}

Den statistiska analysen består av två delar. Först gjordes en kvantitativ analys på aggregerad nivå där undersökningsgruppens behov inom samtliga förekommande livsområden från inskrivnings- respektive utskrivningsformulär jämfördes område för område, variabel för variabel, ett tillvägagångssätt som rekommenderats för analys av underlag från strukturerade intervjuer (Mäkelä 2004). Här gjordes dikotomisering av de femgradiga skattningarna, d.v.s. svaren reducerades till oro/ej oro, förändring/ingen förändring samt stöd/ej stöd.

Därefter genomfördes en fördjupad analys av jämförelsen mellan inskrivning och utskrivning med fokus på individuella variationer beträffande förändring av klienternas angivna behov. Med kontingenstabeller tydliggörs beskrivningen av de individuella variationerna, vilket exemplifieras för samtliga tre förändringsvariabler - upplevd oro, önskad/tillgodosedd förändring samt önskat/tillgodosett stöd och hjälp. Denna modell är specifikt utvecklad för analys av olika former av skattningar, d.v.s. ordinaldata (Svensson 2007).

Slutligen gjordes också en innehållsanalys av en öppen fråga om vad som upplevts särskilt betydelsefullt i behandlingen. Frågan ger en kompletterande bild till de strukturerade frågorna och för de enskilda klienterna en möjlighet att på ett något mer subjektivt och friare sätt ge uttryck för sin syn på behandlingen. Utifrån klienternas olika utsagor gjordes övergripande tematiseringar över innehållet i dem (Esaiasson et al. 2004).

\section{Resultat}

Resultatredovisningen följer analysens struktur och är uppdelad i tre avsnitt. Det första avsnittet sammanfattar undersökningsgruppens förändringar av hjälpbehov på gruppnivå under behandlingstiden, i det andra ges en exemplifiering av hur en fördjupad analys på gruppnivå kan ske med fokus på individuella variationer och i det tredje avsnittet presenteras en analys av uppgifter från en öppen fråga om vad som är betydelsefullt för förändring under behandlingstiden.

\section{Gruppens hjälpbehovoch förändring}

Nedanstående Tabell belyser klientgruppens skattningar av hjälpbehov och om det har skett några förändringar under behandlingstiden. Beskrivningen avser upplevd oro, vilja till förändring och skattad genomförd förändring samt efterfrågat stöd/hjälp och skattning av erhållet stöd/hjälp inom elva olika livsområden, från boendeform till kriminalitet. De ingående variablerna har dikotomiserats för att förenkla jämförelsen mellan inskrivning och utskrivning. Begreppet levnadsform definieras här av intervjuformulärets svarsalternativ inom detta område som exempelvis, ensamlevande, samlevande med partner och samlevande med barn. I livsområdena utbildning och fritid saknas frågan om skattning av upplevd oro i intervjuformuläret.

Tabell 2 visar att klienternas uttryckta oro minskar under behandlingstiden inom de flesta områden, utom beträffande Sys- 
Tabell 2.

En beskrivning av undersökningsgruppens hjälpbehov och förändringar under behandlingstiden.

\begin{tabular}{|c|c|c|c|c|c|}
\hline$n$ & Inskrivning livsområde & $\%$ & $n$ & Utskrivning livsområde & $\%$ \\
\hline & Boendeform: & \multicolumn{4}{|c|}{ Boendeform: } \\
\hline 41 & Oro & 42 & 39 & Oro & 26 \\
\hline 41 & Förändring & 63 & 40 & Förändring & 45 \\
\hline 41 & Stöd och hjälp & 44 & 38 & Stöd och hjälp & 34 \\
\hline & Levnadsform: & \multicolumn{4}{|c|}{ Levnadsform: } \\
\hline 41 & Oro & 61 & 39 & Oro & 38 \\
\hline 41 & Förändring & 85 & 40 & Förändring & 52 \\
\hline 41 & Stöd och hjälp & 63 & 38 & Stöd och hjälp & 58 \\
\hline & Familj och umgänge: & \multicolumn{4}{|c|}{ Familj och umgänge: } \\
\hline 41 & Oro & 54 & 41 & Oro & 46 \\
\hline 41 & Förändring & 78 & 40 & Förändring & 90 \\
\hline 41 & Stöd och hjälp & 44 & 38 & Stöd och hjälp & 87 \\
\hline & Utbildning: & \multicolumn{4}{|c|}{ Utbildning: } \\
\hline 41 & Förändring & 56 & 40 & Förändring & 2 \\
\hline 41 & Stöd och hjälp & 42 & 37 & Stöd och hjälp & 5 \\
\hline & Försörjning: & \multicolumn{4}{|c|}{ Försörjning: } \\
\hline 41 & Oro & 54 & 40 & Oro & 52 \\
\hline 41 & Förändring & 88 & 40 & Förändring & 18 \\
\hline 41 & Stöd och hjälp & 78 & 37 & Stöd och hjälp & 32 \\
\hline & Sysselsättning: & \multicolumn{4}{|c|}{ Sysselsättning: } \\
\hline 41 & Oro & 34 & 41 & Oro & 42 \\
\hline 41 & Förändring & 80 & 40 & Förändring & 32 \\
\hline 41 & Stöd och hjälp & 68 & 39 & Stöd och hjälp & 36 \\
\hline & Fritid: & \multicolumn{4}{|c|}{ Fritid: } \\
\hline 41 & Förändring & 76 & 39 & Förändring & 92 \\
\hline 41 & Stöd och hjälp & 63 & 39 & Stöd och hjälp & 87 \\
\hline & Bruk av droger: & \multicolumn{4}{|c|}{ Bruk av droger: } \\
\hline 41 & Oro & 93 & 41 & Oro & 51 \\
\hline 41 & Förändring & 100 & 40 & Förändring & 100 \\
\hline 41 & Stöd och hjälp & 100 & 40 & Stöd och hjälp & 98 \\
\hline & Fysisk hälsa: & \multicolumn{4}{|c|}{ Fysisk hälsa: } \\
\hline 41 & Oro & 71 & 41 & Oro & 32 \\
\hline 41 & Förändring & 95 & 40 & Förändring & 88 \\
\hline 41 & Stöd och hjälp & 80 & 39 & Stöd och hjälp & 97 \\
\hline & Psykisk hälsa: & \multicolumn{4}{|c|}{ Psykisk hälsa: } \\
\hline 41 & Oro & 90 & 41 & Oro & 39 \\
\hline 41 & Förändring & 95 & 40 & Förändring & 100 \\
\hline 41 & Stöd och hjälp & 95 & 40 & Stöd och hjälp & 92 \\
\hline & Kriminalitet: & \multicolumn{4}{|c|}{ Kriminalitet: } \\
\hline 41 & Oro & 17 & 33 & Oro & 12 \\
\hline 41 & Förändring & 22 & 34 & Förändring & 50 \\
\hline 41 & Stöd och hjälp & 17 & 31 & Stöd och hjälp & 42 \\
\hline
\end{tabular}


selsättning där oron tvärtom har ökat. De livsområden där andelen upplevd oro vid påbörjad och avslutad behandling ligger kvar på ungefär samma nivå är Försörjning, Familj och umgänge samt Kriminalitet. För det senare området är det emellertid få klienter som uttryckt någon oro alls, eftersom det troligen inte har varit relevant.

De största upplevda förändringarna äger rum inom livsområdena Bruk av droger, Fritid, Psykisk hälsa, Familj och umgänge samt Fysisk hälsa. Lägst förändring sker avseende Utbildning, Försörjning och Sysselsättning. Inom områdena Bruk av droger, Fysisk och Psykisk hälsa anser en stor andel klienter att de har gjort förändringar som låg i paritet med de önskemål som uttrycktes vid inskrivningstillfället. När det gäller områdena Familj och umgänge, Fritid samt Kriminalitet har förändringarna varit större än förväntat. En motsatt bild ses inom livsområdena Boendeform, Levnadsform, Utbildning, Försörjning och Sysselsättning, där andelen klienter som fått förändring till stånd är mindre än vad som önskades.

Beträffande klientgruppens efterfrågade och erhållna stöd till förändring framträder en liknande bild som för önskad och genomförd förändring. Stora förändringar sker inom områdena Bruk av droger, Fysisk hälsa, Psykisk hälsa, Familj och umgänge samt Fritid. Vid inskrivning efterfrågade alla eller nästan alla klienter stöd och hjälp inom områdena Bruk av droger och Psykisk hälsa, vilket också klienterna ansåg att de erhållit vid utskrivning. När det gäller Boendeform, Levnadsform, Utbildning, Försörjning och Sysselsättning uppfattade klienterna att stödet erhållits i mindre omfattning än vad som efterfrågades. En mer positiv skattning gjordes för områdena Fysisk hälsa, Fritid, Familj och umgänge samt Kriminalitet där klienterna upplevde att stödet varit större än vad som efterfrågades i samband med påbörjad behandling.

\section{Individuella variationer}

I föregående avsnitt presenterades undersökningsgruppens resultat genom en sammanfattande tabell. För att närmare studera individuella variationer av förändringar i hjälpbehov utfördes även en fördjupad analys. Som exemplifiering av den fördjupade analysen presenteras några av dessa variabler i form av s.k. kontingenstabeller. Den här redovisningsformen för skattningar, d.v.s. ordinaldata, kan bidra till ytterligare förståelse av förändringar och hur avvikelser kan uppstå, genom att åskådliggöra fördelningens mönster på såväl grupp- som individnivå (Svensson 2007).

\section{Tabell 3.}

Klientskattning av oro för problem med bruk av droger vid inskrivning och utskrivning. Följande skattningsskala används: 1. Inte alls, 2. Lite, 3. Ganska, 4. Mycket, 5. Väldigt mycket.

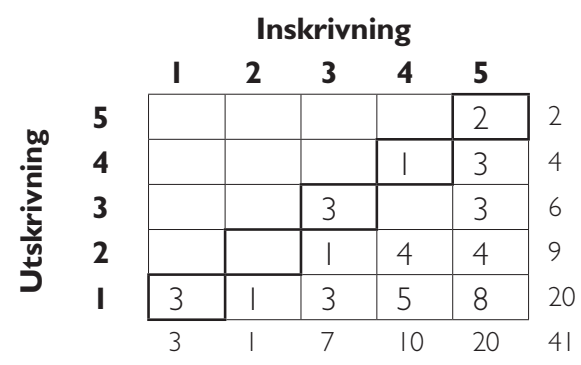

Mikael Dahlberg \& Mats Anderberg: Strukturerade intervjuer som underlag... 
På gruppnivå framgick att den upplevda oron för variabeln Skattning av oro för problem med bruk av droger minskat under behandlingstiden (se Tabell 2). Kontingenstabellen ovan, Tabell 3, beskriver marginalfördelningen mellan påbörjad och avslutad behandling. Som synes finns det en systematisk positiv förändring, där den uttryckta oron för merparten av klienterna har minskat under behandlingstiden. Här framträder också de individuella variationerna. För de klienter som återfinns i diagonalen (nio) kvarstår oron oförändrad, varav tre klienter har uppgivit att de inte alls hyser någon oro för sin droganvändning, varken i samband med påbörjad eller avslutad behandling. För 27 av klienterna har oron minskat med åtminstone två skalsteg, t.ex. från 5. Väldigt mycket till 3. Ganska.

När det gäller nästa exempel, variabeln Vilja till förändring/skattad genomförd förändring inom livsområdet Försörjning,

\section{Tabell 4.}

Vilja till förändring och skattad genomförd förändring av försörjning vid inskrivning och utskrivning. I utskrivningsformuläret àterfinns följande skattningsskala: -2. Mycket sämre, -1. Sämre, 0. Ingen förändring, 1. Bättre, 2. Mycket bättre.

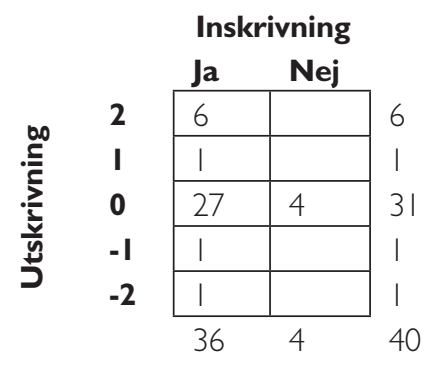

visade det sig att förändring på aggregerad nivå inte har skett för en stor del av undersökningsgruppen. Med nästa kontingenstabell illustreras individernas skattningar för nämnda variabel.

I Tabell 4 framgår att en mycket stor andel, 36 av 40, önskade åstadkomma förändring gällande området Försörjning när behandlingen påbörjas. Enbart 7 klienter av 36 skattade dock att någon form av positiv förändring var genomförd vid utskrivning. Det framgår även att det finns två klienter som skattade sin förändring negativt beträffande försörjning till -1 . Sämre respektive -2. Mycket sämre när behandlingen avslutas.

För att exemplifiera variabeln Behov av stöd och hjälp/skattning av erhället stöd och hjälp redovisas den för området Familj och umgänge. På gruppnivå framgick att fler klienter fick ett betydligt större stöd än vad som efterfrågades.

\section{Tabell 5.}

Behov av stöd/hjälp och skattning av erhàllet stöd/hjälp för problem med familj och umgänge vid inskrivning och utskrivning. Vid utskrivningen används följande skattningsskala: 1. Inte alls, 2. Lite, 3. Ganska, 4. Mycket, 5. Väldigt mycket.

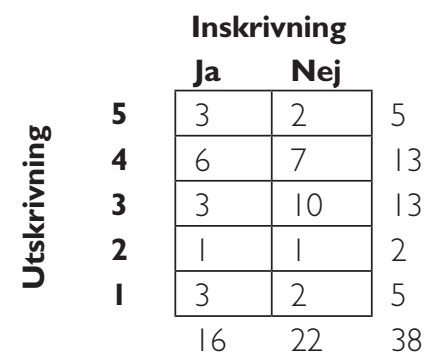


Ovanstående tabell visar att det är 16 av 38 klienter som hade önskemål om stöd och hjälp inom livsområdet Familj och umgänge när behandlingen påbörjas. Vid utskrivningen skattade 33 av 38 klienter att de fått stöd och hjälp med en variation från 2. Lite till 5. Väldigt mycket. Här kan noteras att 20 av 22 klienter som inte uttryckte hjälpbehov vid inskrivning skattade att de fått stöd och hjälp beträffande det aktuella livsområdet vid utskrivning.

\section{Öppna frågor}

Både vid inskrivning och utskrivning återfinns i intervjuformulären en avslutande del med ett antal öppna frågor. Syftet med dessa frågor är att sammanfatta och avsluta intervjusituationen, men också att klienten ges möjlighet till att lämna mer subjektiva uppfattningar om den behandling som planeras respektive den behandling som genomförts. I inskrivningsformuläret finns det tre frågor och där tillfrågas klienten om vad som är positivt och negativt med drogbruk samt om förväntningar på behandlingskontakten. Formuläret som används vid utskrivning innehåller även det tre öppna frågor; klientens upplevelse av behandlingstiden, om klienten fått stöd och hjälp som efterfrågats samt om vad klienten upplevt som betydelsefullt för sin förändring.

Här följer en presentation av det som intervjuerna dokumenterar om vad klienterna upplevt som betydelsefullt när det gäller förändring av sin livssituation sedan inskrivningen. Svarens längd på frågan kan skilja sig åt en del mellan respondenterna, men utgörs oftast av kortfattade meningar, ibland bara med några få summerande ord. Klienternas 88 utsagor har, utifrån sin tillhörighet, sammanförts under fem olika teman eller kategorier: personlig utveckling, behandlingsinslag, drogfrihet, relationer och sociala faktorer. Flera teman kan vara aktuella samtidigt för en och samma klient.

Resultatet, en kvantitativ fördelning, ska ses som exempel på uppgifter som kan hämtas från strukturerade intervjuer och hur de kan analyseras för att utgöra underlag för olika former av lokal utvärdering. Det innebär med andra ord att både uppgifter och kategoriseringar troligen är specifika för olika behandlingsenheter, t.ex. torde en klient inom tvångsvården ge andra synpunkter på vad som är viktigt för förändring av livssituationen.

Ett tema som återkommer i 32 procent av intervjusvaren är personlig utveckling. Här återfinns svar som framförallt handlar om utveckling på det psykiska planet men även några svar som beskriver fysisk utveckling som t.ex. att ha kommit igång med regelbunden träning. Många klienter anser att deras självkänsla och självförtroende har förbättrats under behandlingstiden medan andra uttrycker ett ökat allmänt psykiskt välbefinnande. Det framkommer också att vissa klienter lärt sig hantera sina känslor bättre och menar att de fått en större balans i tillvaron. De har blivit psykiskt stabilare och starkare, några säger också att de blivit mer positiva till livet eller känner mer livsglädje än tidigare. Några tar även upp att de tillägnat sig en större medvetenhet och öppenhet kring hur de mår: "Vågar vara ärlig mot mig själv och omgivningen när det gäller mitt mående."

För 22 procent av klienterna är svaren

Mikael Dahlberg \& Mats Anderberg: Strukturerade intervjuer som underlag... 
kopplade till behandlingen när det gäller vad de har upplevt varit särskilt betydelsefullt för deras förändring. Det är framförallt själva terapin som framhålls, både de individuella samtalen och den terapi som sker i gruppform. Andra poängterar personalens bemötande och behandlingsprogrammets upplägg. Flera klienter tar i samband med detta tema även upp relationen till de andra klienterna, där gemenskapen och kollektivet skapar förutsättningar för trygghet $\mathrm{i}$ behandlingen.

Temat drogfrihet återkommer i 20 procent av svaren. Det inbegriper den uppnådda nykterheten och drogfriheten, d.v.s. att frånvaron av alkohol och droger under behandlingstiden i sig betonas som något väsentligt. När det gäller temat drogfrihet nämns även oron för återfall och att suget eller känslan inför drogen har förändrats. Men även någon slags kunskap eller insikt om hur de framöver ska lyckas vidmakthålla sin förändring, eller som det framgår av ett svar: "Fått hjälp med insikt på ett djupare plan att sluta med alkohol, insikten smög sig på."

Förbättrade relationer till närstående under behandlingstiden, som föräldrar, partners och barn, återkommer i 14 procent av klienternas intervjusvar. Framförallt framhålls relationen till egna barn, som flera klienter särskilt har arbetat med under behandlingen, och önskemål om att återuppta eller förbättra den. Flera menar också att de själva förbättrat sina relationer till andra människor och att deras kontaktnät utökats. Några betonar att de avslutat relationer som inte varit bra för deras positiva utveckling.

Det sista temat är knutet till föränd- ringar som ligger utanför klienternas egen personliga utveckling och berör olika sociala faktorer, tolv procent av intervjusvaren handlar om detta tema. Några säger att de under behandlingsperioden fått nytt arbete och andra att de fått bättre ordning på sin ekonomi. Flera lyfter vid utskrivningen också fram en förändrad boendesituation.

\section{Diskussion}

Denna avslutande del inleds med en sammanfattning av resultaten och därefter diskuteras metodologiska aspekter av systematisk dokumentation inom missbrukarvården utifrån studiens presenterade fall. Det övergripande syftet med denna artikel är att beskriva och diskutera på vilket sätt intervjumetoden DOK kan utgöra underlag för att utvärdera om klienter vid en behandlingsenhet inom missbrukarvården får sina hjälpbehov tillgodosedda under behandlingstiden.

Av det redovisade exemplet framgår att undersökningsgruppen har ett omfattande hjälpbehov inom samtliga presenterade livsområden. När det gäller huruvida hjälpbehoven har blivit tillgodosedda visar uppgifterna från utskrivningsintervjuerna att den största tillfredsställelsen finns inom områdena Bruk av droger, Psykisk hälsa, Familj och umgänge, Kriminalitet, Fysisk hälsa samt Fritid. För övriga områden, Boendeform, Levnadsform, Utbildning, Försörjning och Sysselsättning, är hjälpbehoven i lägre grad tillgodosedda. Här kan särskilt noteras att undersökningsgruppen i mycket hög grad har önskemål om förändring och stöd vid påbörjad behandling som inte har 
kunnat tillgodoses under behandlingstiden, beträffande Utbildning, Försörjning och Sysselsättning (se Tabell 2). Det framgår att strukturerade intervjuer kan användas som underlag för att beskriva förändringar avseende hjälpbehov både på grupp- och individuell nivå. Genom att flera olika livsområden ingår i intervjuerna går det också att få information om graden av förändring inom respektive livsområde.

För att undersöka vad klienterna upplevt som särskilt betydelsefullt för förändring av livssituationen under behandlingstiden analyserades även en av de öppna frågorna i utskrivningsformuläret. Genom en innehållsanalys skapades fem kategorier av klienternas 88 utsagor och fördelningen av svaren blev följande: personlig utveckling (32\%), behandlingsinslag (22\%), drogfrihet (20\%), relationer (14\%) och sociala fakto$\operatorname{rer}(12 \%)$. Analysen av den öppna frågan står i samklang med analysen av de slutna frågorna. De livsområden där störst förändring ägt rum - Bruk av droger, fritid, psykisk hälsa, relationer och fysisk hälsa-kan till stor del även knytas till klienternas uppfattning om vad de ansett har varit särskilt betydelsefullt för dem under behandlingstiden. I intervjusvaren på den öppna frågeställningen framträder motsvarande områden som för de slutna frågorna och kan på så sätt sägas stärka bilden av de livsområden där störst förändring sker. Men de öppna frågorna ger även en fördjupad information utöver det underlag som fås med de bundna frågorna, där klienterna t.ex. framhåller den personliga utvecklingen under behandlingstiden som betydelsefull för förändring.

Studien visar att strukturerade intervjuer bidrar till att klienterna via intervjun ges en möjlighet att skatta sina hjälpbehov vid inskrivning samt värdera hur dessa tillgodosetts vid utskrivning. I traditionell behandlingsforskning undersöks främst graden av nykterhet och drogfrihet. Fallstudien visar att dokumentationen medverkar till att identifiera uttryckta förändringar under behandlingen även inom flera andra livsområden, något som i sin tur ger en mer heltäckande och nyanserad bild av klienters förändring på såväl individ- som gruppnivå. Den senare nivån kan härigenom bidra till kunskap om den behandling som ges, både för livsområden där klienternas behov tillgodosetts och där efterfrågat stöd inte erhållits, något som i sin tur kan ligga till grund för kvalitets- och metodutveckling. Studien ger härigenom ett konkret exempel på hur strukturerade intervjuer kan utgöra ett underlag för att utvärdera en lokal verksamhet.

\section{Metodologiska aspekter}

Huruvida klienternas uttryckta förändringar också speglar deras verkliga förändringar är mer osäkert. Två aspekter av den via intervjuer insamlade dokumentationen är av stor betydelse för att kunna identifiera förändringar under en social intervention. Dels finns det brister i in- och utskrivningsintervjuernas jämförbarhet inom ett antal livsområden, t.ex. fritid och utbildning, där frågan om skattning av oro vid inskrivning och utskrivning saknas. Dels saknas det ett antal frågeställningar i utskrivningsintervjun som också belyser den rapporterade faktiska förändringen som komplement till de subjektiva skattningar som klienten

Mikael Dahlberg \& Mats Anderberg: Strukturerade intervjuer som underlag... 
gör inom de olika frågeområdena. Särskilt som det i tidigare metodologiska studier visat sig att klientens skattningar inte tycks vara tillräckligt tillförlitliga för att utgöra underlag för behandlingsplanering eller för användning i forskningssammanhang (Anderberg \& Dahlberg 2008). Därför är det viktigt att inte låta enbart skattningar utgöra underlag vid en lokal utvärdering, utan bilden behöver också kompletteras med variabler som syftar till att fånga de mer "faktiska" förändringarna (se Andreasson 2003, McLellan et al. 2006). När det specifikt gäller det instrument som studerats i den här undersökningen, $\mathrm{DOK}$, går det att med små medel genomföra revideringar som innebär en större harmonisering mellan inskrivnings- och utskrivningsintervju.

Ytterligare en aspekt av förändring är hur den mäts och analyseras - att valet av statistisk metod också har betydelse för vilken information som kan utvinnas. Vanligtvis görs mer beskrivande sammanställningar över klienters förändringar, där olika variabler summeras till sammanfattande mått eller s.k. sumscores (se t.ex. Jess \& Nyström 2002). Något som leder till att informationen blir begränsad och inte tillräckligt precis eller tillförlitlig för att användas som underlag för utvärdering eller forskning (Jansson 2001, Svensson 2007). Risken är också att individuella förändringsmönster "dränks» i en alltför sammanfattande bild. Ett alternativ är istället att följa varje enskild klients förändring och att analysera varje variabel utifrån sin mätnivå (t.ex. ordinaldata, skattningar, som kräver särskilda analysmetoder). I resultatredovisningen ges en exemplifiering (Tabell 3-5) på en analysmetod som är utvecklad för att beskriva förändringar på såväl grupp- som individnivå.

I vilken utsträckning det är klientens egna ord som återges i de öppna frågorna är dock en källa till ovisshet, eftersom det är intervjuaren som registrerar svaren. Utsagorna kan därmed ha omtolkats av denne i samband med utskrivningen. Klienterna kan ha uppgett ett utförligt svar som sedan sammanfattats så att viktiga nyanser gått förlorade eller kan innehålla uppgifter som inte noterats alls (Sudman et al. 1996).

En annan aspekt som kan förekomma vid intervjuer av den här typen är att svaren till viss del kan präglas av social önskvärdhet, d.v.s. att respondenten via sina svar ställer sig själv och sin förändring i en mer positiv dager eller uttrycker sig mer positivt om det hon eller han varit med om (Midanik 1989). Troligen framträder detta fenomen mer i den öppna frågeställningen där klienten som tagit emot behandling för sina missbruksproblem kanske vill "ge något tillbaka» till den behandlare som genomför utskrivningsintervjun:

\section{Behavioral therapists have referred to this} phenomenon as the 'hello-goodbye' effect in which clients tend to 'over' present their symptoms upon entering treatment and 'under' present their symptoms upon completion of treatment (Midanik 1989 s. 1422).

En förutsättning för att man ska kunna ta fram användbar kunskap för lokal utvärdering är att samtliga klienter genomgår behandlingen som planerat och inte avbryter den i förtid. Då kan både lång inskrivnings- och utskrivningsintervju komma till 
stånd, en ambitionsnivå som inte alltid är genomförbar (Larsson \& Segraeus 2005, Alexandersson, 2006). Med ett betydande bortfall när det gäller långa utskrivningsintervjuer blir det problem att dra relevanta slutsatser med verksamhetens insamlade data som grund. Det är en metodologisk aspekt som inte i tillräcklig omfattning uppmärksammats i diskussionen kring lokal uppföljning och utvärdering. Myndigheter tycks ta för givet att samtliga klienter har ett optimalt behandlingsförlopp och att lokala behandlingsenheter har tid och möjlighet att genomföra en fullständig (lång) dokumentation vid såväl inskrivning och utskrivning som uppföljning. För många behandlingsenheter är det svårt att få till stånd en sammanhängande dokumentation, vilket även framgår av studien. Problemet har emellertid diskuterats tidigare, redan för drygt tio år sedan förespråkade Bergmark och Oscarsson (1996) av den anledningen en basdokumentation, d.v.s. en komprimerad strukturerad intervju som ändå möjliggjorde uppföljning och utvärdering av behandling. I ett stort amerikanskt forskningsprojekt, det s.k. DENS (Drug Evaluation Network System) där ASI-intervjun har utgjort grund, har det också visat sig att det är den kortare versionen (ASI-Lite) som har använts i störst omfattning (Carise et al. 1999).

\section{Avslutande reflektioner}

Att belysa de förändringar som sker för klienterna under själva behandlingstiden är en rimlig utvärderingsansats för olika typer av behandlingsenheter inom missbruksvården. När det gäller uppföljning en tid efter avslutad behandling kräver det betydligt större arbetsinsatser och resurser och är därmed en huvudsaklig uppgift för forskningen. Däremot torde det vara möjligt att verksamheterna själva kan ta reda på och redogöra för om klienterna fått sina hjälpbehov tillgodosedda och i vilken grad är de nöjda med den behandling de fått.

Som underlag för en kunskapsbaserad praktik och en forskning som försöker identifiera verksamma behandlingsmetoder behövs det en grundläggande och kontinuerlig dokumentation om missbruksvårdens klienter och interventioner. Denna konklusion ligger även i linje med flera andra forskares slutsatser (Bergmark \& Oscarsson 1996, Bergmark \& Lundström 2007):

I det långa loppet framstår detta som den enda vägen mot att utveckla professionella förhållningssätt inom den socialtjänstbaserade missbrukarvairden. Att systematiskt dokumentera vissa uppgifter om sina klienter och om den behandling, de insatser dessa fär är ett första steg i en sådan utveckling (Bergmark \& Oscarsson 1996 s. 47).

En viktig slutsats som kan dras utifrån den här fallstudien är att strukturerade intervjuer som DOK eller ASI kan användas för utvärdering på lokal nivå. Denna kunskap har dock begränsningar vad gäller generaliserbarhet, men kan ändå ha en stor giltighet för den "givna arenan" (Börjeson 2006). Med relativt enkla medel kan en verksamhet få en relevant bild av sammansättningen av klienter, men också hur klienterna ser på sin förändring och på den hjälp de erhållit under behandlingstiden. Det går med stöd av de empiriska resultaten också att urskilja

Mikael Dahlberg \& Mats Anderberg: Strukturerade intervjuer som underlag... 
inom vilka områden klienterna uppfattar att de genomgått störst förändringar och fått mest hjälp, eller identifiera livsområden där de tvärtom uttrycker missnöje. Denna kunskap kan sedan användas som underlag för diskussion, kritisk reflektion av den egna verksamheten och för metodutveckling (Jenner \& Segraeus 2005, Socialstyrel- sen 2001). I en kommande studie kommer de i den här undersökningen medverkande klienterna att följas upp sex månader efter avslutad behandling, i syfte att undersöka på vilket sätt strukturerade intervjuer kan användas för att belysa deras mer långsiktiga förändringar och behandlingsresultat.

\section{Litteraturlista}

Alexandersson, K. (2006) Vilja, kunna, förstå. Om implementering av systematisk dokumentation för verksamhetsutveckling inom socialtjänsten. Örebro: Universitetsbiblioteket.

Anderberg, M. \& Dahlberg, M. (2007) „Interbedömarreliabilitet - ett tillförlitligt mått på standardiserade intervjuer? En studie av DOKintervjun." Nordisk alkohol- och narkotikatidskrift(1), s. 45-58.

Anderberg, M. \& Dahlberg, M. (2008) "You get what you ask for - a study of the validity of the DOC interview». Submitted.

Andréasson, S. (red.) (2003) ASI: en strukturerad intervjumetod för bedömning av alkohol- och narkotikarelaterade problem. Rev.version. Stockholm: Centrum för utvärdering av socialt arbete.

Bergmark, A. \& Oscarsson, L. (1992) „Den imiterade verkligheten. Om autenticitetsproblemet inom missbrukarvården." I C. Mether \& L. Nygren (red.) Bortom all förenkling. Människan som väsen och oväsen. Uddevalla: Daidalos.

Bergmark, A. \& Oscarsson, L. (1996) „Basdokumentation för socialtjänstens missbrukarvård." I M. Berglund (red.) Dokumentation inom missbrukarvården: behandlingsarbete, metodutveckling, utvärdering. Stockholm: Centrum för utvärdering av socialt arbete.

Bergmark, Å. \& Lundström, T. (2007) "Att studera rörliga mål - om villkoren för evidens och kunskapsproduktion i socialt arbete."Socionomens forskningssupplement (3), s. 4-16.
Billquist, L. \& Johnsson, L. (2007) "Sociala akter som empiri. Om möjligheter och svårigheter med att använda socialarbetares dokumentation i forskningssyfte." Socialvetenskaplig tidskrift(1), s. 3-19.

Blomqvist, J. (2000) "Att sluta missbruka behandling och andra inflytanden." I M. Berglund (red.) Behandling av alkoholproblem. En kunskapsöversikt. Stockholm: Centrum för utvärdering av socialt arbete.

Börjeson, B. (2005) „Kunskapens språk eller språket om kunskapen.»IS. Ljunggren (red.). Empiri - Evidens - Empati. Nordiska röster om kunskapsutvecklingen i socialt arbete. Århus: Nordiska ministerrådet och Nopus.

Börjeson, B. (2006) "Socialarbetaren och kunskapsneurosen." I B. Blom, S. Morén och L. Nygren (red.). Kunskap i socialt arbete. Stockholm: Natur och Kultur.

Carise D, McLellan A T, Gifford L, \& Kleber H D (1999) "Developing a National Addiction Treatment Information System. An Introduction to the Drug Evaluation Network System." Journal of Substance Abuse Treatment. 17 (1-2), pp. 67-77.

Dahlberg, M. \& Anderberg, M. (2008) „Om strukturerade frågor och tillförlitliga svar i missbruks- och beroendevården - en reliabilitetsstudie av intervjumetoden DOK." Socialmedicinsk tidskrift nr. 2 s. 164-174.

Engström, C. \& Armelius, B-Å. (2002) »Klienters acceptans av strukturerade intervjuer i soci- 
altjänsten." Nordisk Sosialt Arbeid (4), s. 210216.

Esaiasson P, Gilljam M, Oscarsson H \& Wängnerud L (2004) Metodpraktikan. Konsten att studera samhälle, individ och marknad. Stockholm: Nordstedts Juridik AB.

Finney, J.W. (2003) »Assessing Treatment and Treatment Processes». I Assessing Alcohol Problems. Bethseda: National Institutes of Health.

Hill, C.E. \& Lambert, M.J. (2004) „Metholodical Issues in Studying Psychotherapy Processes and Outcomes." In M.J. Lambert (ed.) Bergin and Garfield's Handbook of Psychotherapy and Behaviour Change. $5^{\text {th }}$ Edition. New York: Wiley.

Jansson I. (2001) Problem i sammanfattande mått $i$ ASI. Stockholm: Statens institutionsstyrelse.

Jenner, H. \& Segraeus, V. (2005) "The Swedish DOC-system - an attempt to combine documentation and self-evaluation." European Addiction Research 11 (4), pp. 186-192.

Jess, K. \& Nyström, S. (2002) "En investering i socialt arbete." Socialvetenskaplig tidskrift (2-3), s. 240-260.

Larsson, J. \& Segraeus, V. (2005) Från tvång till frihet. Stockholm: Statens institutionsstyrelse.

Lauritzen, G. \& Ravndal, E. (2004) "Introduction of the EuropASI in Norway: Clinical and research experiences from a cost-effectiveness study." Journal of Substance Use 9 (3-4), pp. 141-146.

McLellan T, McCay J R, Forman R, Cacciola J \& Kemp J (2005) »Reconsidering the evaluation of addiction treatment: from retrospective followup to concurrent recovery monitoring." Addiction 100, pp. 447-458.

McLellan A T, Cacciola J S, Alterman A I, Rikoon S H \& Carise D (2006) »The Addiction Severity Index at 25: Origins, Contributions and Transitions." The American Journal on Addictions Vol 15, pp. 113-124.

Midanik, L.T. (1989) "Perspectives on the Validity of Self-Reported Alcohol Use." British Journal of Addiction 84, pp. 1419-1423.

Miller, W.R. \& Wilcombe, P.L. (2002) „Mesa Grande: a methodological analysis of clinical trials of treatments for alcohol use disorders." Addiction 97, pp. 265-277.

Mäkelä, K. (2004) „Studies of the reliability and validity of the Addiction Severity Index." Addiction 99, pp. 398-410.

Oscarsson, L. (2006) „Evidenskravet och socialt arbete. Skiss till en strategi för forskning och praktik.»Socionomen nr. 4 s. 31-34.

Rossi P, Lipsey M \& Freeman H (2003) Evalutation. A Systematic Approach. 7 Edition. Thousand Oaks: Sage Pubilcations.

SBU-rapport (2001) Behandling av alkohol- och narkotikaproblem - En evidensbaserad kunskapssammanställning. Volym I och II. Stockholm: SBU.

Socialstyrelsen (2001) Nationellt stöd för kunskapsutveckling inom socialtjänsten. SoS-rapport nr. 2001:12. Stockholm: Socialstyrelsen.

Socialstyrelsen (2002) Utvärdering av FoU - En studie av FoU-enheter inriktade på Individ- och familjeomsorg. Stockholm: Socialstyrelsen.

Socialstyrelsen (2004) Systematisk bedömning inom socialtjänsten. Stockholm: Socialstyrelsen.

Socialstyrelsen (2007) Nationella riktlinjer för missbruks- och beroendevaird. Stockholm: Socialstyrelsen.

Stenius, K. \& Room, R. (2004) »Measuring 'addiction' in Europe: The diffusion of the Addiction Severity Index, and its purposes and functions."I Journal of Substance Use 9 (3-4), pp. 105-119.

Sudman S, Bradburn N M \& Schwarz N (1996) Thinking about Answers. The Application of Cognitive Processes to Survey Methodology. San Fransisco: Jossey-Bass Publishers.

Svensson, E. (2007) „Vad är behandlingseffekt om patienten blev bättre, men ingen vet hur mycket bättre? Statistisk metod för parade ordinaldata." Läkartidningen $\mathrm{nr} 8 \mathrm{Vol}$ 104, s. 596-601.

Tengvald, K. (2006) »Mer beprövad erfarenhet för klienters och brukares bästa.« Socionomen nr 4, s. $70-74$.

Yin, R.K. (2003) Case Study Research. Design and Methods. Third Edition. Thousand Oaks: Sage Publications.

Mikael Dahlberg \& Mats Anderberg: Strukturerade intervjuer som underlag... 


\section{Summary}

\section{Structured interviews as a foundation for evaluation and research Some methodological issues}

The aim of the article is to describe and discuss how the interview method "DOK" can constitute a foundation for evaluating to what extent clients in a unit for treatment of substance abuse have their needs met during the treatment period.

The study is based on a case where the data was collected via structured interviews in connection with the beginning and end of treatment. In total 41 clients were interviewed by the DOK interview method.

The case study shows that the data contributes to identifying changes during the treatment period within many different areas of life. This gives a more comprehen- sive and balanced picture of the clients' changes on both an individual and a group level. The latter gives insight into the treatment delivered, both in life areas where the clients' needs were met, and in areas where their required support was not received, thus creating a foundation for quality and method development. Evidence-based practice, and research trying to identify effective treatment methods, requires basic and continual documentation about the clients, and the interventions in the substance abuse care. The study can serve as an example of how structured interviews can constitute a foundation for an evaluation per treatment unit. 